UDC 159.963.322.3-616.89

DOI: $10.26565 / 2410-1249-2020-13-04$

\title{
CBT OF ANXIETY AND DEPRESSIVE DISORDERS IN FOREIGN MEDICAL STUDENTS
}

\section{Vadym Sinaiko}

MD, Doctor of science, professor, department of Psychiatry, Narcology, Medical Psychology and Social Work, Kharkiv National Medical university

E-mail:vmsinaiko@ukr.net

Liliia Korovina

MD, PhD, associated professor, department of Psychiatry, Narcology, Medical Psychology and Social Work, Kharkiv National Medical university

E-mail: l-korovina@ukr.net

Tetiana Radchenko

$M D, P h D$, assistant professor, department of Psychiatry, Narcology Medical Psychology and Social Work, Kharkiv National Medical university

E-mail: tatyanalradchenko@gmail.com

\begin{abstract}
The article discusses the use of cognitive-behavioral therapy in foreign medical students. It is well known thatdepression is the second most common disease in the world. The causes of depression are diverse. Different psychological schools see this disorder from different perspectives. Recently, we are increasingly seeing mixed anxiety-depressive episodes. Learning a medicine in a foreign language is an additional stress factor. Thus, the selected contingent needs a psychotherapeutic effect for adaptation. The article provides information on cognitivebehavioral therapy taking into account the gender characteristics of the contingent. In our opinion, cognitivebehavioral therapy is an optimal and short-term method of psychotherapeutic influence. Thus, a differentiated approach to the preparation of therapeutic programs based on the gender characteristics of anxiety-depressive disorder is effective and can be recommended for use with medical students.
\end{abstract}

KEY WORDS: depression, anxiety, cognitive-behavior therapy, foreign medical students, gender.

Introduction. Depression is not only one of the most common forms of mental illness. This pathology is ahead of the spread of many human diseases and second only to arterial hypertension. According to $\mathrm{WHO}$, the prevalence of depressive disorders is about $15 \%$ and is constantly increasing (Napriyenko, 2013; Diagnostic and statistical, 2013).

Mood disorders associated have a multifactorial etiology and pathogenesis. These include genetic factors, metabolic disorders of neurotransmitters, neuroendocrine disorders, psychosocial factors. Among a large group of psychosocial factors, acute and chronic factors of stress, mental trauma, childhood injuries (including those displaced into the unconscious), frustrations, existential crises, and nativistic thinking are distinguished (Kozhyna, 2016; Mishyev, 2004; Napriyenko, 2013; Chisholm, 2016).

In the modern world, we often talk about the comorbidity of mental pathology. Classical, described in the first half of the twentieth century, mental disorders are almost not found today. If we are talking about depressive disorders, then in recent years they are mainly represented by anxietydepressive disorders. Nowadays, there are often cases when it is quite difficult to differentiate anxiety and depression. Diagnostic criteria such as impaired attention span, insomnia, and fatigue can occur in both conditions (Kozhyna, 2016; Mishyev, 2004; Kholmogorova, 2011; Chisholm, 2016; Diagnostic and statistical, 2013].

Different psychological schools have different points of view on the problem of depression. From the perspective of psychoanalysis, I believe that the loss of self-esteem resources is important for the development of depression. That is, numerous stresses hit precisely on the mechanisms that support self-esteem. At the same time, many psychoanalysts, including Z. Freud, considered depression to be characteristic of an adult, as life is filled with a large number of situations of the loss of an object. And the situation of experiencing premature loss of the object is the main factor in the development of depression according to Abraham (Vestbruk, 2014; 
Kholmogorova, 2011; Cuijpers, 2016; Rasing, 2017).

From the point of view of the existential approach, depression can be considered as a special crisis of experiencing the values of life, fundamental relationships with life, the values of the world and oneself (mental, somatic, personological components) (Vestbruk, 2014; Cuijpers, 2016).

We can see that people with some variant of depression have some abnormalities of components of cognitive function. They can have selectivity in memory processes. From the standpoint of cognitive theory, depression can be represented by negative self-perception, negative perception of the world, expectation of trouble. That is, at the level of oneself, the world and the future, there is negative thinking, which determines the mental state of a person. If we will try to explain depression from cognitive theory study, we will see a lot of different point of view inside it. Here they are information-ProcessingBased Models, Social-Cognitive Models, BecheviorCognitive Models etc (Vestbruk, 2014; Napriyenko, 2013; Ingram, 1998).

In our opinion, it is cognitive-behavioral therapy that allows us to understand the mechanisms of development of depression, including anxietydepressive states, and correct them. This method allows you to search and solve a problem in a person, and not in the surrounding world. Cognitive patterns, cognitive distortions, automatic thoughts that cause the predominance of negative thoughts, they determine negative thinking. CBT allows the client to see, as if from the outside, their beliefs, evaluate them and adjust them. This method allows you to work with thoughts and feelings in a complex, and to form an adaptive model of behavior. (Vestbruk, 2014; Ingram, 1998; Morrison, 2001; Rasing, 2017).

Aim of the study. The aim of this study was to develop a short-term cognitive-behavioral (CBT) psychotherapeutic correction for students of foreigners of the English-language form of study at a medical university.

Contingent and methods of the research. Our study involved 40 students of both sexes. Of these, 21 are women and 19 are men. All students studied at the Kharkov National Medical University in 4-5 courses. The training was in English. The age of the study population is from 20 to 25 years. The criteria for inclusion in the study were: the presence of complaints and a subjectively conscious decrease in mood and activity, the presence of anxiety; foreign citizens studying at the English-language faculty. Exclusion criteria: age more than 30 years, the presence of one's own family, the intake of any psychotropic medications, the presence of severe somatic or neurological diseases, the presence of comorbid mental pathology.

The study was carried out in the middle of the semester, when students had already returned from vacation and fully engaged in the educational rhythm. At the same time, they were not exposed to additional stress associated with the need to receive final semester grades or pass tests and exams.

We used clinical, psychopathological, clinical and medical history, psychodiagnostic methods (hospital scale of anxiety and depression, HADS).

The results of the study. The conducted study revealed the manifestations of clinically expressed depression and anxiety in the examined students. According to the anxiety subscale (HADS), the result averaged $12.4 \pm 0.7$ points. At the same time, there were no significant differences by gender. In men, this indicator corresponded to $12.26 \pm 0.6$ points, and in women $12.52 \pm 0.3$ points. According to the subscale of depression, the result was $13.6 \pm 0.9$ points. Moreover, in men it was $13.7 \pm 0.6$ points, and in women $13.5 \pm 0.3$ points.

All examined students had complaints of early insomnia. That is, they could not fall asleep for a long time, but fell asleep after 2-3 a.m. At the same time, 18 women $(85.7 \%)$ noted that they could not fall asleep due to "fear or anxiety". 5 women of them $(23.8 \%)$ noted anxiety of varying severity, and 13 women $(61.9 \%)$ - fears, which were mainly represented by fear of the dark, mystical experiences (fear of ghosts), fear of dying. 3 female students $(14.3 \%)$ could not indicate the cause of insomnia. In men, insomnia was associated with anxiety in only 4 people (21.1\%). Fears (darkness, death) were experienced by $3(15.8 \%)$ examined. The remaining 12 male students $(63.1 \%)$ could not clearly indicate the reason for prolonged falling asleep. 
A distinctive feature of English-speaking foreign students is their desire to study and live with representatives of their countries and even regions. This is largely due to the desire to speak native languages or dialects even if the official language of instruction was all English. To maintain the optimal level of psychological and social adaptation of students, this feature had to be taken into account both in the formation of academic groups at the beginning of each academic year, and in regular work with students.

Almost all the students examined during the previous years of study at the university tried to change the academic group into which they were distributed. 33 students (16 women and 17 men), changing their place of residence, tried to move in with their friends or move closer to their relatives in Kharkov. They explained this activity by the desire to defend themselves, but did not get the effect. 29 students (16 women and 13 men) considered these changes a mistake and experienced a strong negative affect in this regard. In 19 students of them (12 women and 9 men), it was accompanied by the dominance of the idea of their own insignificance due to incorrect forecasting of the situation.

All examined students were offered therapeutic correction. It included individual sessions of shortterm CBT. This work included three stages. At the first stage, a therapeutic alliance was established, and a request was formed. This stage lasted an average of 2-3 sessions. At the second stage, work was carried out with negative cognitive distortions, inadequate social interaction, and the formation of an active life position. This stage lasted 20 sessions. At the third stage, they sought the development of new attitudes, completed the therapy. This stage lasted 2 sessions.

At the very beginning of the therapeutic work, a strong separation of the contingent was revealed. In a detailed analysis of the available information, it turned out that the contingent is not homogeneous in some respects depending on the gender factor. All female students noted a tendency to over eating due to a stress. That is, they reported that over the past 1-2 years they began to eat significantly more. The menu was dominated by fast carbohydrates, fast food. At the same time, none of the students noted that they began to cook more. On the contrary, they noted that most of the food was bought ready-made. 12 female students (57.1\%) noted that they began to cook at home no more than 1 time per week. All students noted an increase in body weight. At the same time, 8 of them (38.1\%) added 15 or more $\mathrm{kg}$ over the past year.

All female patients significantly limited their exits from home. They went out only if necessary: visiting a supermarket and university. 7 (33,3\%) of them reported fear of leaving one house and dependence on the activity of their friends. At the same time, 16 students $(76,2 \%)$ reported that they came to classes, only because they did not want to work of missed classes in the future.

Male students reported that they spent more time outside the home. At the same time, they either walked aimlessly around the city or visited places / acquaintances where they used psychoactive substances. All of them had a large number of missed classes, and 16 of them had significant academic debt, conflicts in the university and with other students. All mail contingent tended to drink alcohol and nicotine daily. $15(78,9 \%)$ of them reported that they do this because they understand that psychoactive substances destroy the body.

Most male students noted a feeling of loneliness, but there was not such a brightly subjectively painful manifestation of it as in women. Men filled their time with computer games and being on social networks. Women experienced it subjectively very hard.

The second stage of therapeutic work significantly differed among the male and female contingents. Strategies for improving adaptation have been developed for men, taking into account trends in addictive behaviors and aggression. These were mainly behavioral experiments and methods of adoption, planning, problem solving.

Strategists were proposed for the female students, based on the specifics of their condition. That is, they had negative automatic thoughts and distortions due to a significant immersion in negative affect. They were offered techniques aimed at breaking the cycles of negative affect. All women studied had successful social skills trainings. 
Regardless of the strategies chosen, the suicide risk was monitored for the entire study continent.

The third stage of therapy did not significantly differ in the examined individuals. It included completion of therapy, enrichment of knowledge to prevent a possible relapse of the condition, optimization of previously mastered techniques and exercises.

After these therapeutic sessions, the all contingent of the study noticed much better feeling. 38 students $(92.5 \%)$ had a good, quality night's sleep. The entire study contingent reported a significant increase in daily activity. 32 students (80\%) reported of activation of out of class activity (sports, outdoor activities, hobbies) 4-5 times a week.

The entire study population was re-examined using the HADS scale. According to the subscale of anxiety, the result in all examined patients averaged $6.5 \pm 0.7$ points. At the same time, there was no significant gender difference. In men, this indicator corresponded to $6.8 \pm 0.4$ points, and in women 6.1 \pm 0.4 points. According to the subscale of depression, the result was $6.6 \pm 0.7$ points. Moreover, in men it was $6.6 \pm 0.5$ points, and in women $6.5 \pm 0.3$ points.

Conclusions. Thus, we can say that the proposed psychotherapeutic correction has shown its effectiveness. It should be noted that when conducting CBT, even in a group that is homogeneous in nosological form, it is necessary to take into account the existing gender differences. Additional studies of the contingent can make CBT more differentiated and significantly improve the result of therapy.

\section{REFERENCES}

Vestbruk, D., Kennerli, G., Kirk J. (2014). Вступ у когнітівноповедінкову терапію [Introduction to cognitivebehavioral therapy]. Lviv: Svichado.

Kozhyna, G.M., Markova, M.V., Marakushyn, D.I., Zelenska, K.O. et al. (2016). Комплексна система психопрофілактики розвитку станів дезадаптації у студентів перших років навчання [Complex system of psychoprophylaxis of development of maladaptation states in students of the first years of study]. Archiv Psyhiatrii. 22(4), 51-55.

Mishyev, V.D. (2004). Сучасні депресивні розлади: Керівництво для лікарів [Сучасні депресивні розлади: Керівництво для лікарів]. Lviv: Ms.

Napriyenko, O.L., Loganovskyi, K.M., Syropyatov, O.G. (2013). Нециркулярні депресї: монографія [Noncircular depressions: a monograph]. Napriyenko O.K. (Ed.). Kyiv: Сoфiя-A.

Kholmogorova, A.B. (2011). Интегративная психотерапия расстройств аффективного спектра [Integrative psychotherapy for affective spectrum disorders]. Moscow: Medpraktika-M.

Chisholm, D., Sweeny, K., Sheehan, P. et al (2016). Scaling-up treatment of depression and anxiety: a global return on investment analysis. Lancet Psychiatry. 3(5), 415-424, https://doi.org/10.1016/S2215-0366(16)30024-4.

Cuijpers, P., Donker, T., Weissman, M.M. (2016). Interpersonal Psychotherapy for Mental Health Problems: A Comprehensive Meta-Analysis. The American Journal of Psychiatry. 173(7), 680-687. https://doi.org/10.1176/appi.ajp.2015.15091141.

Diagnostic and statistical manual of mental disorders: DSM-5. $5^{\text {th }}$ ed., (2013).

Ingram, R.E., Miranda, J., Segal, Z.V. Ingram, R.E. (1998). Cognitive vulnerability to depression. NY: The Guilford Press.

Morrison, N. (2001). Group cognitive therapy: treatment of choice or suboptimal option. Behav. Cogn. Psychother. 29, 311-332.

Rasing, S.P.A., Creemers, D.H.M., Janssens, J.M.A.M. et al. (2017). Depression and Anxiety Prevention Based on Cognitive Behavioral Therapy for At-Risk Adolescents: A Meta-Analytic Review. S.P.A. Rasing, Frontiers in Psychology. https://doi.org/10.3389/fpsyg.2017.01066.

КПТ ТРИВОЖНИХ ТА ДЕПРЕСИВНИХ РОЛАДІВ МОВИ У ІНОЗЕМНИХ МЕДИЧНИХ СТУДЕНТІВ

Вадим Синайко

Доктор наук, професор кафедри психіатрії, наркології, Медичної психології та соиіальної роботи, Харківський національний медичний університет Лілія Коровіна

Кандидат психологічних наук, дочент кафедри психіатрії, наркології, Медичної психології та сочіальної роботи, Харківський наиіональний медичний університет

Тетяна Радченко

Кандидат психологічних наук, дочент кафедри психіатрії, наркології, Медичної психології та сочіальної роботи, Харківський начіональний медичний університет У статті обговорюється використання когнітивно-поведінкової терапії у іноземних студентів-медиків. Добре відомо, що депресія є другим за поширеністю захворюванням у світі. Причини депресії різноманітні. Різні психологічні школи бачать цей розлад з різних точок зору. Останнім часом ми все частіше спостерігаємо змішані тривожно-депресивні епізоди. Вивчення ліків іноземною мовою $\epsilon$ додатковим стресовим фактором. Таким чином, вибраний контингент потребує 
психотерапевтичного ефекту для адаптації. У статті подано інформацію про когнітивно-поведінкову терапію з урахуванням гендерних особливостей контингенту. На нашу думку, когнітивно-поведінкова терапія є оптимальним та короткочасним методом психотерапевтичного впливу. Таким чином, диференційований підхід до підготовки терапевтичних програм на основі гендерних особливостей тривожно-депресивного розладу є ефективним і може бути рекомендований для використання студентам-медикам.

КЛЮЧОВІ СЛОВА: депресія, тривога, когнітивно-поведінкова терапія, іноземні студенти-медики, стать.

\section{КПТ ТРЕВОЖНЫХ И ДЕПРЕССИВНЫХ РАССТРОЙСТВ У ИНОСТРАННЫХ СТУДЕНТОВ-МЕДИКОВ}

Вадим Синайко

Доктор наук, профессор кафедры психиатрии, наркологии, Медицинской психологии и социальной работы, Харьковский начиональный медицинский университет

Лилия Коровина

Кандидат психологических наук, доиент кафедры психиатрии, наркологии, Медииинской психологии и соичильной работы, Харьковский национальный медицинский университет

Татьяна Радченко

Кандидат психологических наук, доцент кафедры психиатрии, наркологии, Медииинской психологии и соџиальной работы, Харьковский национальный медицинский университет В статье рассматривается использование когнитивно-поведенческой терапии у иностранных студентов-медиков. Хорошо известно, что депрессия является вторым наиболее распространенным заболеванием в мире. Причины депрессии разнообразны. Разные психологические школы видят это расстройство с разных точек зрения. В последнее время мы все чаще наблюдаем смешанные тревожно-депрессивные эпизоды. Изучение медицины на иностранном языке является дополнительным стрессовым фактором. Таким образом, выбранный контингент нуждается в психотерапевтическом эффекте для адаптации. В статье представлена информация о когнитивно-поведенческой терапии с учетом гендерных особенностей контингента. По нашему мнению, когнитивно-поведенческая терапия является оптимальным и кратковременным методом психотерапевтического воздействия. Таким образом, дифференцированный подход к составлению терапевтических программ, основанный на гендерных характеристиках тревожно-депрессивного расстройства, эффективен и может быть рекомендован для использования студентами-медиками.

КЛЮЧЕВЫЕ СЛОВА: депрессия, тревожность, когнитивно-поведенческая терапия, иностранные студенты-медики, пол 